Www.jmscr.igmpublication.org

Impact Factor (SJIF): 6.379

Index Copernicus Value: 79.54

ISSN (e)-2347-176x ISSN (p) 2455-0450

crossrefDOI: https://dx.doi.org/10.18535/jmscr/v7i1.60

Journal Of Medical Science And Clinical Research

IGM Publication

An Official Publication of IGM Publication

\title{
Research Paper \\ Biochemical Changes in Betel Quid Chewers and Non Chewers in Tribal Population of Udaipur District
}

\author{
Authors \\ Nita Sahi ${ }^{1}$, Shrish Sharma ${ }^{2}$, Shubham Jain ${ }^{3}$ \\ ${ }^{1}$ Associate Professor Dept. of Biochemistry Pacific Medical College \& Hospital Udaipur (Rajasthan), India. \\ ${ }^{2,3}$ PG Student Dept. of Biochemistry Pacific Medical College \& Hospital Udaipur (Rajasthan), India \\ Email: bsntshrm83@gmail.com, Mob.9929405806
}

\begin{abstract}
Background: Betel quid chewing is ancient, socially acceptable and often combined with tobacco chewing, is a common habit in the Indian subcontinent. A mixture of betel leaf, areca nut, and tobacco chewing is used in many parts of India. Development of malignancy of the oral mucosa and foregut is mainly associated with betel quid chewing. Betel nut chewing is associated with increased production of reactive oxygen species and inflammatory mediators, which could potentially cause kidney damage.

Aim of study: Biochemical changes in betel quid chewers and non chewers in Udaipur district of Rajasthan. Study Area: The present study was conducted in PMCH, Udaipur.

Study Design: The study was design and undertaken in the Central laboratory of PMCH Udaipur. The cases of this study compare the changes in betel quid chewers and non chewer's patients.

Statistical Analysis: Data thus collected was entered in Microsoft excel 2007 Worksheet in the form of master chart. These data were classified and analyzed as per the aims and objectives.

Result: During the research study blood examination was done to find out change in biochemical parameters in betel nut chewers and non-chewers groups. The purpose of this study was to comparatively estimate the biochemical parameters of betel quid chewers with their respective controls. The plasma glucose, serum enzymes such as AST, ALT level were increased in betel quid chewers when compared to non-chewers.

Conclusion: A direct association was detected, though the results were less convincing. Furthermore, betel chewing may impose a greater risk than smoking. More effort on developing betel chewing cessation programs is urgently warranted.

Keywords: AST, ALT, Serum Glucose, Betel quid chewers, Non-chewers, Biochemical analysis.
\end{abstract}

\section{Introduction}

Betel nuts are the fruits of the areca palm (name, areca catechu, family, Palmacea) which grows in the tropical environments. The palm is indigenous to India and South Pacific, but apparently can be grow in many other warm locations including
Florida and California. Oral mucosa response in different ways to quid ${ }^{1}$. Quid is a substance or mixture of substances that is placed in the mouth, where it is sucked or actively chewed and thus remains in contact with the mucosa over an extended period. It usually contains one or both of 
2 basic ingredients, tobacco, and areca nut ${ }^{2}$. Quid are of three types (1) Quid with areca nut without tobacco products (pan or betel quid [BQ]), (2) Quid with tobacco products without areca nut (chewing tobacco, moist, and dry snuff), (3) Quid with both areca nut and tobacco products (Gotha). ${ }^{2}$

The quid is prepared by wrapping chopped areca nuts (betel nuts) in a leaf of the vine, Piper betel. Tobacco and lime may be added to improve the taste. The quid is known colloquially as 'pan'. Areca nut causes submucosal fibrosis, which has a known malignant potential ${ }^{3}$. It may also be associated with asthma and has been shown to have a diabetogenic effect in mice. It is estimated that 10 to $25 \%$ of the population chew betel quid.

Betel nut is believed by user to be a mild stimulant, which produces an increased awareness of one's surrounding. It acts as psychoactive and addictive properties. It is the fourth most commonly, used psychoactive substance after caffeine, nicotine and alcohol ${ }^{4}$.

In spite of lekoplakia, betel nut chewing has been linked variety of problems albuminuria in diabetic patients, disruption of gastric mucosal barriers, aggravation of asthma induction of pyramidal syndrome, milk alkali syndrome, induction of dysplasia, cancer of the oesophagus, and liver and low birth weight of babies born to mother chewing betel nut. All these things are associated with betel quid cheweing $^{4-5}$.

\section{Materials and Method}

Study Area: The present study was conducted in $\mathrm{PMCH}$, Udaipur.

Study Design: The study was design and undertaken in the Central laboratory of $\mathrm{PMCH}$ Udaipur. The cases of this study compare the biochemical changes in betel quid chewers and non chewers.

Study period: Jan. 2018 to oct.2018

\section{Sample Population:}

All male patients who are consuming betel quid for more than three years without having any systemic disease of Udaipur fulfilling inclusion criteria till sample size achieved or end of study period whichever is earlier.

Sample size: We divide our 40 samples in 20 cases and 20 as control group.

\section{Inclusion Criteria}

A total of 40 patient's (20)/controls (20) was select in Tribal area in Udaipur, Rajasthan.

\section{Exclusion Criteria}

Patient with the following diseases or histories will be excluded from the study:

- Trace elements medication

- Alcoholism

- Kidney disease

- Liver disease

- Patients with diabetic keto acidosis

- Patients who are currently taking nutritional supplementations

- Subjects who have acute complication such as severe infections, major trauma

All diagnosed patients were further evaluated for present study by routine biochemical investigations and specific laboratory investigations. All laboratory investigations were carried out in the clinical Biochemistry laboratory, of Department of Biochemistry on Auto analyzer and semi Auto analyzer.

\section{Collection of blood}

The blood samples were collected in betel quid chewers by a venous puncture in a heparinized tube. Serum and plasma were separated by centrifugation at $3000 \mathrm{rpm}$ for 15 minutes. The separated plasma serum was used for the investigation. Biochemical parameters were analyzed on semi auto analyzer (Chem- 5 Plus v2 model) using standard kits supplied by Erba. Glucose, serum glutamate Oxaloacetate Transaminase, and Serum Glutamate Pyruvate Transaminase.

\section{Statistical Analysis}

Statistical analyses were performed by using spss. The results were expressed as mean \pm S.D. 
Observation \& Result

Table 1 Biochemical analysis of $B Q$ chewers

\begin{tabular}{|l|c|c|c|}
\hline $\begin{array}{l}\text { Serial } \\
\text {.No. }\end{array}$ & PARAMETRES & $\begin{array}{c}\text { NON- } \\
\text { CHEWERS }\end{array}$ & CHEWERS \\
\hline 1. & $\begin{array}{c}\text { SERUM } \\
\text { GLUCOSE } \\
\text { (mg/d) }\end{array}$ & $96.450 \pm 2.481$ & $162.30 \pm 17.980$ \\
\hline 2. & AST (IU/L) & $18.050 \pm 0.826$ & $41.660 \pm 4.129$ \\
\hline 3. & ALT (IU/L) & $23.500 \pm 1.792$ & $44.480 \pm 4.620$ \\
\hline
\end{tabular}

Values are expressed as mean \pm sd, $\mathrm{n}=20$, ALT: Alanine aminotransferase, AST : Aspartate aminotansferase, SD : standard deviation.

During the research study blood examination was done to find out change in biochemical parameters in betel nut chewers and non-chewers groups. The purpose of this study was to comparatively estimate the biochemical parameters of betel quid chewers with their respective controls. In the present study, biochemical changes in betel quid chewers when compared non-chewers were presented in Table 1.

The plasma glucose, serum enzymes such as AST, ALT, level were increased in betel quid chewers when compared to non-chewers.

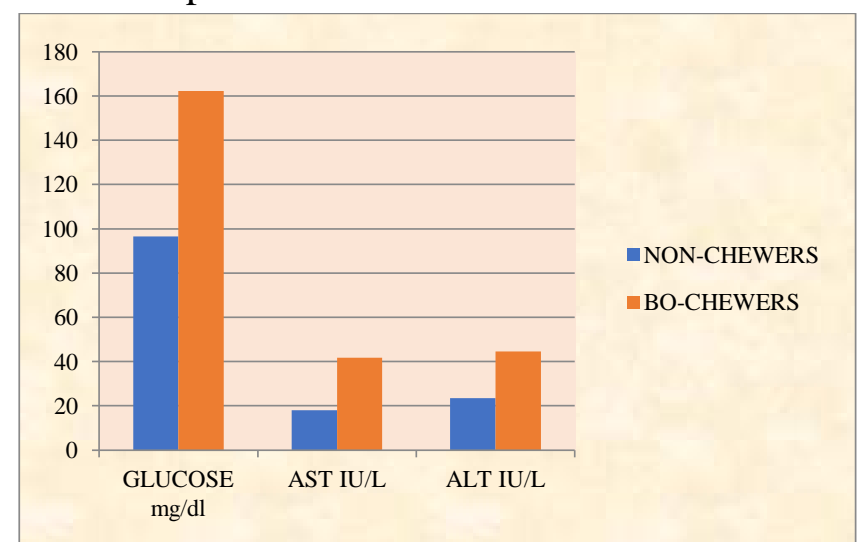

Graph 1 showing serum Glucose, AST, ALT levels in BQ chewers and non chewers.

\section{Discussion}

Betel nut consumption can be viewed as a public health hazards in parts of the world. Betel nut consumption can be viewed as a public health hazards in parts of the world, the habit of spitting the juice on the street can increase the spread of diseases such as tuberculosis ${ }^{[5]}$. In spite of lekoplakia, betel nut chewing has been linked variety of problems albuminuria in diabetic patients ${ }^{[6]}$, disruption of gastric mucosal barriers, aggravation of asthma, induction of pyramidal syndrome, milk alkali syndrome, induction of dysplasia $^{[10]}$, cancer of the oesophagus, and liver and low birth weight of babies born to mother chewing betel nut.

According to some studies Betel quid mainly contains four arecal alkaloids (primarily arecoline, but also arecaidine, guvacine and guvacoline), with arecoline causing short-term hypoglycaemia. The arecal alkaloids also produce nitrosamine derivatives, that found to be potential factor for diabetogenic and carcinogenic effects ${ }^{(9)}$

Other than this some studies also shows the Betel quid as a source of exposure to trace levels of some heavy metals, some of which, such as arsenic or manganese, may found to increase risk of hypertension ${ }^{(10-11)}$

It appears to be related to elevated homocysteine, a risk factor for heart disease. $(3,7)$ Betel quid chewing can also induce periodontal disease, a known risk factor for cardiovascular disease (CVD). ${ }^{12}$

In more recent population based studies in Nepal, betel nut chewing is also associated with higher risk of type 2 diabetes mellitus ${ }^{[14]}$, hypertension [15], and total cerebrovascular deaths, and sub clinical ischemic heart disease in diabetic patients. In our study results indicated that there is increased in serum glucose, AST, ALT in BQchewers. That is why people are not paying attention to give up this bad habit of chewing betel nut and getting involved in continuing till its bad effects control the body metabolism. So that is why it has been part of Asian culture and tradition. Its cheap price and easy availability are spreading it very fastly. In tribal areas betel quid chewing become a common habit of the entire age groups person as they are youngster or older people. Therefore our government should take some precautionary steps to save society from all types of hazardous substances which are licking health like termite.

\section{Conclusion}

Betal quid chewing continues to be widespread in tribal populations of Rajasthan Betel chewing may 
impose a greater risk than smoking. ${ }^{(16)}$ The plasma glucose, serum enzymes such as AST, ALT level were increased in betel quid chewers when compared to non-chewers.

\section{References}

1. IARC Working Group on the Evaluation of Carcinogenic Risks to Humans. Betelquid and areca-nut chewing and some areca-nut-derived nitrosamines.IARCMonogrEvalCarcinogR isksHum2004;85:1-334

2. Boucher BJ, Ewen SWB, Stowers JM. Betel nut (Areca catechu) consumption and the in duction of glucose intolerance in adult CD1miceand in their F1 and F2 offspring. Diabetologia 1994;37:49-5

3. Tung TH, Chiu YH, Wu HM, Boucher BJ, Chen THH. A population based study of the association between areca-nut chewing and type 2 diabetes mellitus in men.Diabetologia2004;47:1776-

81.(KCISno.2.)

4. Boucher BJ,MannanN.Metabolic effects of the consumption of Areca catechu. Addict Biol 2002; 7:103-10.

5. Zain RB, Ikeda N, Gupta PC, Warnakulasuriya KAAS, van Wyk $\mathrm{CW}$,Shrestha $\mathrm{P}$, and other. Oral mucosal lesions associated with betel quid, Areca nut and tobacco chewing habits: consensus from a workshop held In Kuala Lumpur, Malaysia, November 25-27, 1996. J Oral Pathol Med 1999; 28(1):1-4

6. Greenberg . Glick . Ship. Burket"s oral medicine. 11th edition,page 100-101.

7. Zain $\mathrm{R}$ B, Ikeda N, Gupta $\mathrm{P} C$, Warnakulasuriya S, van Wyk C W, Shrestha P, Axell T. Oral mucosal lesions associated with betel quid, areca nut and tobacco chewing habits: consensus from a workshop held in Kuala Lumpur, Malaysia. November 25-27, 1996. J Oral Path Med1999: 28: 1-4.
8. Boucher BJ, Mannan N. Metabolic effects of the consumption of Areca catechu. Addict Biol 2002;7:103-10.

9. IARC Working Group on the Evaluation of Carcinogenic Risks to Humans., World Health Organization., International Agency for Research on Cancer. Betelquid and areca-nut chewing and some areca-nut-derived nitrosamines. Lyon, France: IARC Press, 2004.

10. Al-Rmalli SW, Jenkins RO, Haris PI. Betel quid chewing elevates human exposure to arsenic, cadmium and lead. J Hazard Mater 2011;190:69-74

11. Lee BK, Kim Y. Relationship between blood manganese and blood pressure in the Korean general population according to KNHANES 2008. Environ Res 2011;111: 797-803.

12. Knekt P, Alfthan G, Aromaa A et al. Homocysteine and major coronary events: a prospective population study amongst women. J Intern Med 2001;249:461-65.

13. Parmar G, Sangwan P, Vashi P, Kulkarni $\mathrm{P}$, Kumar S. Effect of chewing a mixture of areca nut and tobacco on periodontal tissues and oral hygiene status. J Oral Sci 2008;50:57-62

14. Fogh-Andersen N, Wimberley PD, Thode J, Siggaard-Andersen O. Direct reading glucose electrodes detect the molality of glucose in plasma and whole blood. Clin Chim Acta 1990; 189: 33-38.

15. Henry, R. J., et al., Amer. J. Clin. Path., 34:381 (1960).

16. Ramya M, Anuradha R Biochemical Changes In Betel Quid Chewers And NonChewers of Kakkarai, Thanjavur District of Tamilnadu in Asian J Pharm Clin Res, Vol 8, Issue 3, 2015, 122-124 